\title{
Coccinellidae Parasitoids in Brazil: Neglected Species in a Mega-Diverse Country
}

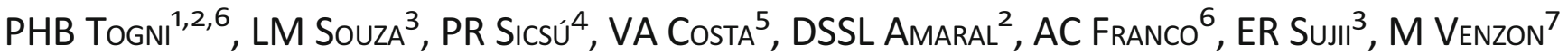 \\ 'Univ Paulista, Campus Brasília, Brasília, DF, Brasil \\ ${ }^{2}$ Depto de Entomologia, Univ Federal de Viçosa, Viçosa, MG, Brasil \\ ${ }^{3}$ Embrapa Recursos Genéticos e Biotecnologia, Brasília, DF, Brasil \\ ${ }^{4}$ School of Life Sciences, Arizona State Univ, Tempe, AZ, USA \\ ${ }^{5}$ Centro Experimental do Instituto Biológico, Instituto Biológico, Campinas, SP, Brasil \\ ${ }^{6}$ Depto de Zoologia, Univ de Brasília, Brasília, DF, Brasil \\ ${ }^{7}$ Empresa de Pesquisa Agropecuária de Minas Gerais - EPAMIG/UREZM, Viçosa, MG, Brasil
}

\section{Keywords}

Biodiversity, ladybirds, neotropical region, parasitization

\section{Correspondence}

PHB Togni, Univ Paulista, Campus Brasília, Quadra SGAS 913 Asa Sul, CEP: 70390130 Brasília, DF, Brasil; phbtogni@gmail.com

Edited by Roberto A Zucchi - ESALQ/USP

Received 2 December 2014 and accepted 8 June 2015

(C) Sociedade Entomológica do Brasil 2015

\begin{abstract}
Current knowledge on coccinellids is primarily focused on their role as natural enemies of soft-bodied insects. However, there is a great diversity of coccinellid parasitoid species that are less studied. Here, we describe new records of coccinellid parasitoids with emphasis on new host-parasitoid interactions in 11 sample sites in Brazil. We collected 122 coccinellid individuals parasitized by six species of parasitoids in the Cerrado and in the Atlantic Rainforest biomes. New records of coccinellid parasitoids and host associations, expansion of habitat ranges and interactions are discussed focusing on the lack of basic information on these interactions in Brazil.
\end{abstract}

Coccinellids are one of the most studied group of predators of soft-bodied insects worldwide (Michaud 2012). They are part of complex food webs acting at the same time as predators, competitors, intraguild predators and prey (Lucas 2012). The knowledge on these predator species and their interactions is widespread, but information on their parasitoid species are less studied and understood. So far, there are nearly 100 known coccinellid parasitoid species (Riddick et al 2009), and although the diversity of parasitoids of coccinellids is still growing, the records are concentrated in temperate regions such as Europe, Japan and the USA (Ceryngier et al 2012).

Therefore, there are only a few records of coccinellid parasitoid species in tropical and mega-diverse regions. In Brazil, for example, the few records available were made by Gravena (1978), Berti-Filho \& Costa (1995) and Silva et al (2012). Here, we describe new records of coccinellid parasitoids with emphasis on new host-parasitoid interactions in two biomes considered hotspots of biodiversity in Brazil. The information we provide highlights the lack of basic information on coccinellid parasitoids in this mega-diverse country.

The study was conducted in agricultural areas in Brazil, four of them in the state of Minas Gerais and seven in the Federal District, from November 2008 to December 2011 (Table 1). Collection sites in Minas Gerais were located in the Zona da Mata, a region in the Atlantic Rainforest biome. The region has a tropical highland climate with an average temperature of $19^{\circ} \mathrm{C}$ and an average precipitation of $1800 \mathrm{~mm}$ per year. The collection sites in the Brazilian Federal District were located in the Central Plateau region in the core of the Cerrado biome, the Brazilian tropical savanna. The climate in this location is semi-humid with mean temperatures ranging from 22 to $27^{\circ} \mathrm{C}$, an average rainfall of $1200 \mathrm{~mm}$ per year and a marked dry season (Klink \& Machado 2005). 
Table 1 Coccinellids parasitized by distinct species of parasitoids collected in different regions and habitats in Brazil, $2008-2011$.

\begin{tabular}{|c|c|c|c|c|}
\hline Parasitoid taxon & City, state* & Collection sites & Geographical Coordinates & Parasitized coccinellids \\
\hline \multicolumn{5}{|l|}{ Hymenoptera } \\
\hline \multicolumn{5}{|l|}{ Braconidae } \\
\hline \multirow[t]{10}{*}{ Dinocampus coccinellae } & Viçosa, MG & Multiple crops & $20^{\circ} 45^{\prime} 14^{\prime \prime} \mathrm{S}, 42^{\circ} 52^{\prime} 54^{\prime \prime} \mathrm{W}$ & $\begin{array}{l}\text { Cycloneda sanguinea; } \\
\text { Coleomegilla maculata }\end{array}$ \\
\hline & Viçosa, MG & Orchard & $20^{\circ} 45^{\prime} 14^{\prime \prime} \mathrm{S}, 42^{\circ} 52^{\prime} 54^{\prime \prime} \mathrm{W}$ & Cycloneda sanguinea \\
\hline & Piranga, MG & Pumpkin crop & $20^{\circ} 45^{\prime} 4^{\prime \prime} \mathrm{S}, 43^{\circ} 18^{\prime} 10^{\prime \prime} \mathrm{W}$ & Cycloneda sanguinea \\
\hline & Piranga, MG & Chilli pepper crop & $20^{\circ} 45^{\prime} 4^{\prime \prime} \mathrm{S}, 43^{\circ} 18^{\prime} 10^{\prime \prime} \mathrm{W}$ & Cycloneda sanguinea \\
\hline & Brasília, DF & Genetically modified cotton & $15^{\circ} 43^{\prime} 37^{\prime \prime} \mathrm{S}, 47^{\circ} 57^{\prime} 56^{\prime \prime} \mathrm{W}$ & Cycloneda sanguinea \\
\hline & Taguatinga, DF & Organic vegetable crops & $15^{\circ} 49^{\prime} 48.5^{\prime \prime} \mathrm{S}, 48^{\circ} \mathrm{0} 4^{\prime} 13.4^{\prime \prime} \mathrm{W}$ & Cycloneda sanguinea \\
\hline & Samambaia, DF & $\begin{array}{l}\text { Organic vegetable crops and } \\
\text { agroforestry }\end{array}$ & $15^{\circ} 50^{\prime} 41^{\prime \prime} \mathrm{S}, 48^{\circ} 4^{\prime} 26^{\prime \prime} \mathrm{W}$ & Cycloneda sanguinea \\
\hline & Rajadinha, DF & Organic vegetable crops & $15^{\circ} 45^{\prime} 44.9^{\prime \prime} \mathrm{S}, 47^{\circ} 38^{\prime} 28.9^{\prime \prime} \mathrm{W}$ & Cycloneda sanguinea \\
\hline & Ceilândia, DF & $\begin{array}{l}\text { Organic vegetable crops and } \\
\text { agroforestry }\end{array}$ & $15^{\circ} 49^{\prime} 31.2^{\prime \prime} \mathrm{S}, 48^{\circ} 15^{\prime} 6^{\prime \prime} \mathrm{W}$ & Cycloneda sanguinea \\
\hline & Brazlândia, DF & Organic strawberry crop & $15^{\circ} 40^{\prime} 21.96^{\prime \prime} \mathrm{S}, 48^{\circ}$ og' 52.39" W & Harmonia axyridis \\
\hline \multicolumn{5}{|l|}{ Eulophidae } \\
\hline \multirow[t]{2}{*}{ Aprostocetus sp. } & Brasília, DF & Genetically modified cotton & $15^{\circ} 43^{\prime} 37^{\prime \prime} \mathrm{S}, 47^{\circ} 57^{\prime} 56^{\prime \prime} \mathrm{W}$ & Cycloneda sanguinea \\
\hline & Brasília, DF & Agroforestry & $15^{\circ} 43^{\prime} 48^{\prime \prime} S, 47^{\circ} 54^{\prime} 1^{\prime \prime} \mathrm{W}$ & Cycloneda sanguinea \\
\hline \multicolumn{5}{|l|}{ Encyrtidae } \\
\hline \multirow[t]{5}{*}{ Homalotylus terminalis } & Brasília, DF & Agroforestry & $15^{\circ} 43^{\prime} 48^{\prime \prime} S, 47^{\circ} 54^{\prime} 1^{\prime \prime} W$ & Cycloneda sanguinea \\
\hline & Brazlândia, DF & Organic strawberry crops & $15^{\circ} 40^{\prime} 21.96^{\prime \prime} \mathrm{S}, 48^{\circ}$ o9' 52.39" W & Hippodamia convergens \\
\hline & Samambaia, DF & $\begin{array}{l}\text { Organic vegetable crops and } \\
\text { agroforestry }\end{array}$ & $15^{\circ} 49^{\prime} 31.2^{\prime \prime} \mathrm{S}, 48^{\circ} 15^{\prime} 6^{\prime \prime} \mathrm{W}$ & Cycloneda sanguinea \\
\hline & Taguatinga, DF & Organic vegetable crops & $15^{\circ} 49^{\prime} 48.5^{\prime \prime} \mathrm{S}, 48^{\circ} \mathrm{0} 4^{\prime} 13.4^{\prime \prime} \mathrm{W}$ & Cycloneda sanguinea \\
\hline & Ceilândia, DF & $\begin{array}{l}\text { Organic vegetable crops and } \\
\text { agroforestry }\end{array}$ & $15^{\circ} 49^{\prime} 31.2^{\prime \prime} \mathrm{S}, 48^{\circ} 15^{\prime} 6^{\prime \prime} \mathrm{W}$ & Cycloneda sanguinea \\
\hline \multicolumn{5}{|l|}{ Pteromalidae } \\
\hline \multirow[t]{2}{*}{ Pachyneuron aphidis } & Brasília, DF & Genetically modified cotton & $15^{\circ} 43^{\prime} 37^{\prime \prime} \mathrm{S}, 47^{\circ} 57^{\prime} 56^{\prime \prime} \mathrm{W}$ & Cycloneda sanguinea \\
\hline & Brasília, DF & Agroforestry & $15^{\circ} 43^{\prime} 48^{\prime \prime} S, 47^{\circ} 54^{\prime} 1^{\prime \prime} \mathrm{W}$ & Cycloneda sanguinea \\
\hline \multicolumn{5}{|l|}{ Diptera } \\
\hline \multicolumn{5}{|l|}{ Tachinidae } \\
\hline \multirow[t]{3}{*}{ Strongygaster brasiliensis } & Viçosa, MG & Multiple crops & $20^{\circ} 45^{\prime} 14^{\prime \prime} \mathrm{S}, 42^{\circ} 52^{\prime} 54^{\prime \prime} \mathrm{W}$ & $\begin{array}{l}\text { Cycloneda sanguinea; } \\
\text { Harmonia axyridis }\end{array}$ \\
\hline & Piranga, MG & Chilli pepper crop & $20^{\circ} 45^{\prime} 4^{\prime \prime} \mathrm{S}, 43^{\circ} 18^{\prime} 10^{\prime \prime} \mathrm{W}$ & Cycloneda sanguinea \\
\hline & Brazlândia, DF & Organic strawberry crop & $15^{\circ} 40^{\prime} 21.96^{\prime \prime} \mathrm{S}, 48^{\circ}$ o9' 52.39" W & Harmonia axyridis \\
\hline \multicolumn{5}{|l|}{ Phoridae } \\
\hline Phalacrotophora nedae & Brasília, DF & Agroforestry & $15^{\circ} 43^{\prime} 48^{\prime \prime} S, 47^{\circ} 54^{\prime} 1^{\prime \prime} W$ & Cycloneda sanguinea \\
\hline
\end{tabular}

*MG Minas Gerais, DF Federal District.

Larvae, pupae and adults of coccinellids were collected during 1 week per month, except in the field where trials with genetically modified cotton were performed in the Federal District. Coccinellids were collected in a fortnightly basis during the cotton crop season from November/2008 to February/2009 and from November/2009 to February/ 2010. Insects were collected directly over randomly selected plants during $2 \mathrm{~h}$ per day in each sample site. Samples were focused mainly on Cycloneda sanguinea L. (Coleoptera: Coccinellidae) in order to establish a stock rearing of this species in the laboratory for further bioassays.
Nevertheless, other coccinellids were occasionally sampled, such as Coleomegilla maculata (DeGeer) and Harmonia axyridis (Pallas), and were collected as well.

Field-collected individuals were taken to the laboratory $\left(25 \pm 1^{\circ} \mathrm{C}, 75 \% \mathrm{RH}\right)$. Adults were coupled, fed with the laboratory-reared aphids Aphis gossypii Glöver and Myzus persicae (Sulz.), and kept inside plastic pots $(500 \mathrm{~mL})$. Fieldcollected larvae and pupae were individualized in plastic pots $(50 \mathrm{~mL}$ ), and larvae were fed with the same diet provided to the adults. Samples were checked twice a week and the food sources replaced ad libitum. When symptoms of 
parasitization were detected (e.g. immobility or death), coccinellids were kept separated until parasitoid emergency. The number of parasitoids that emerged per host was recorded. Hymenopteran parasitoids were identified by one of us (VAC), while dipteran parasitoids were sent to other taxonomists for species identification. Voucher specimens were deposited in the following institutions: Centro Experimental do Instituto Biológico (all Hymenoptera species), Departamento de Zoologia in the Universidade de Brasília (Tachinidae species) and Universidade de São Paulo (Phoridae species).

We collected a total of 122 individuals (larvae, pupae and adults) comprising four species of coccinellids parasitized by six species of parasitoids in agricultural areas in the Cerrado and in the Atlantic Rainforest biomes (Table 1). Adult coccinellids were parasitized by the solitary parasitoid Dinocampus coccinellae (Schrank) (Hymenoptera: Braconidae) and Strongygaster brasiliensis (Towsend)
(Diptera: Tachinidae). Dinocampus coccinellae was the most abundant in our samples (30\% from all parasitized individuals collected; $59.4 \%$ of all adult coccinellids parasitized) and they were found in all sample sites, except in the agroforestry, parasitizing three species of adult coccinellids (Tables 1 and 2). Strongygaster brasiliensis was recorded in only three sample sites (Table 1) associated with two coccinellid species (Table 2), and comprised $40.61 \%$ of the adult coccinellids parasitized. The gregarious Phalacrotophora nedae (Malloch) (Diptera: Phoridae) was the only species parasitizing a coccinellid pupa, and it was collected in just one habitat type (Tables 1 and 2), being the least abundant in our samples $(2.5 \%$ from all collected coccinellid parasitoids) (Tables 1 and 2).

Three species of gregarious larval parasitoids were recorded on two species of coccinellids (Table 1). Homalotylus terminalis (Say) (Hymenoptera: Encyrtidae) was found in four habitats parasitizing larvae of two species of coccinellids, while Pachyneuron aphidis (Bouché) (Hymenoptera:

Table 2 Species of coccinellid parasitoids that parasitized different developmental stages of their hosts and mean number ( \pm SD) of parasitoids per host collected in different regions and habitats in Brazil, 2008-2011.

\begin{tabular}{lllll}
\hline Parasitoid taxon $\quad$ Host & $\begin{array}{l}\text { Host } \\
\text { stage }\end{array}$ & $\begin{array}{l}\text { Individuals } \\
\text { parasitized }\end{array}$ & $\begin{array}{l}\text { Number of } \\
\text { parasitoids } \\
\text { emerged from } \\
\text { each host } \\
\text { (min-max) }\end{array}$ & Parasitoid \\
& & classification & \\
& & & \\
& &
\end{tabular}

\begin{tabular}{|c|c|c|c|c|c|c|}
\hline \multicolumn{7}{|l|}{ Hymenoptera } \\
\hline \multicolumn{7}{|l|}{ Braconidae } \\
\hline \multirow[t]{3}{*}{$\begin{array}{r}\text { Dinocampus } \\
\text { coccinellae }\end{array}$} & Cycloneda sanguinea & Adult & 36 & 1 & Solitary & \multirow{3}{*}{$\begin{array}{l}\text { First record in the Brazilian Atlantic } \\
\text { Rainforest and first record } \\
\text { parasitizing } H . \text { axyridis in Brazil }\end{array}$} \\
\hline & Coleomegilla maculata & Adult & 1 & 1 & Solitary & \\
\hline & Harmonia axyridis & Adult & 1 & 1 & Solitary & \\
\hline \multicolumn{7}{|l|}{ Eulophidae } \\
\hline Aprostocetus sp. & Cycloneda sanguinea & Larvae & 9 & $4.0 \pm 1.94(1-6)$ & Gregarious & $\begin{array}{l}\text { First record parasitizing } C \text {. sanguinea } \\
\text { and first record parasitizing } \\
\text { coccinellids in South America }\end{array}$ \\
\hline \multicolumn{7}{|l|}{ Encyrtidae } \\
\hline \multirow[t]{2}{*}{$\begin{array}{c}\text { Homalotylus } \\
\text { terminalis }\end{array}$} & Cycloneda sanguinea & Larvae & 27 & $4.7 \pm 1.77(1-8)$ & Gregarious & \multirow{2}{*}{$\begin{array}{l}\text { First record in Brazil and first } \\
\text { record parasitizing } H \text {. convergens } \\
\text { in Brazil }\end{array}$} \\
\hline & $\begin{array}{l}\text { Hippodamia } \\
\text { convergens }\end{array}$ & Larvae & 2 & $3.0 \pm 1.41(2-4)$ & Gregarious & \\
\hline \multicolumn{7}{|l|}{ Pteromalidae } \\
\hline $\begin{array}{l}\text { Pachyneuron } \\
\text { aphidis }\end{array}$ & Cycloneda sanguinea & Larvae & 17 & $4.9 \pm 2.59(1-13)$ & Gregarious & $\begin{array}{l}\text { First record parasitizing coccinellids } \\
\text { in Brazil. First record parasitizing } \\
\text { C. sanguinea }\end{array}$ \\
\hline \multicolumn{7}{|l|}{ Diptera } \\
\hline \multicolumn{7}{|l|}{ Tachinidae } \\
\hline \multirow[t]{2}{*}{$\begin{array}{c}\text { Strongygaster } \\
\text { brasiliensis }\end{array}$} & Cycloneda sanguinea & Adult & 21 & 1 & Solitary & \multirow{2}{*}{$\begin{array}{l}\text { New coccinellid parasitoid and } \\
\text { first record parasitizing } C \text {. sanguinea } \\
\text { and } H \text {. axyridis }\end{array}$} \\
\hline & Harmonia axyridis & Adult & 5 & 1 & Solitary & \\
\hline \multicolumn{7}{|l|}{ Phoridae } \\
\hline $\begin{array}{l}\text { Phalacrotophora } \\
\text { nedae }\end{array}$ & Cycloneda sanguinea & Pupae & 3 & $3.0 \pm 1.73(1-4)$ & Gregarious & First record in the Cerrado biome \\
\hline
\end{tabular}

*New interactions refer to new records related to each parasitoid species. 
Pteromalidae) and Aprostocetus sp. (Hymenoptera: Eulophidae) were found in only two habitats on one coccinellid species (Tables 1 and 2). Homalotylus terminalis was the most abundant larval parasitoid $(52.7 \%$ from the parasitized larvae) followed by $P$. aphidis (30.9\%) and Aprostocetus sp. (16.4\%).

The record of $D$. coccinellae on $H$. axyridis is the first for Brazil, and its low abundance in our sampling is probably due to the recent arrival of $H$. axyridis in our sample site areas (Rezende et al 2010, Harterreiten-Souza et al 2012) and to our preferential sampling of $C$. sanguinea.

Strongygaster brasiliensis has been recorded on coleopteran (Guimarães 1978, Mikami \& Ventura 2008) and hemipteran (Guimarães 1977) hosts in Brazil, but our records are the first on coccinellids as hosts for this species. Coccinellids are known as hosts for the genus Strongygaster, as several records are available for Strongygaster triangulifera (Loew) in North America (Ceryngier et al 2012, O'Hara 2014).

Phalacrotophora nedae was previously recorded parasitizing other coccinellids exclusively in South America, including C. sanguinea in Brazil (Gravena 1978). Nevertheless, our record extends its geographical range as it is the first for this species in the Cerrado biome.

More than half of the known species of Homalotylus parasitizes coccinellids or has some association with coccinellids (Ceryngier et al 2012), but our records for $H$. terminalis are the first for this species in Brazil and it is the first for its association with Hippodamia convergens. Previous records of this species were made in North and Central America, Guyana and Uruguay parasitizing mainly Coccinellinae, including C. sanguinea (Noyes 2014).

Pachyneuron aphidis was collected in only two sample sites in the Cerrado biome parasitizing $C$. sanguinea. There are only six species of this genus recorded in association with coccinellids, which are presumably secondary parasitoids (Ceryngier et al 2012). Most of their host species are Aphididae, but they also parasitize other Hemiptera, Coleoptera, Diptera and Lepidoptera species and are recorded as secondary parasitoids of Aphelinidae, Braconidae (Aphidiinae), Encyrtidae, Figitidae (including Charipinae) and Platygastridae (Noyes 2014). We are sure that $P$. aphidis was parasitizing $C$. sanguinea larvae because we isolated parasitized coccinellids and fed the larvae with aphids reared in controlled conditions (free of aphid parasitoids). Thus, this is the first record of this species parasitizing $C$. sanguinea and the first record of a Pachyneuron species parasitizing coccinellids in Brazil.

It was not possible to identify the species of Aprostocetus specimens because there are no keys for the New World fauna and systematics of this genus is problematic. They were found in the same habitats and parasitizing the same host of $P$. aphidis (Table 1). Aprostocetus neglectus Domenichini and Aprostocetus esurus Riley are the only two species of Aprostocetus recorded parasitizing coccinellids, and they are usually secondary parasitoids (Ceryngier et al 2012). In our study, we found one adult of Aprostocetus sp. that emerged together with three $H$. terminalis adults from the same coccinellid larva. As some species of Aprostocetus are recognized as secondary parasitoids (Noyes 2014), we presume that they were using C. sanguinea as secondary hosts.

Our study demonstrated an unknown diversity of interactions between coccinellids and parasitoids, even while sampling in agricultural lands in only two biomes in Brazil. Coccinellid parasitoids occur in a wide variety of habitats and can interact with several species of coccinellids. This implies that the occurrence of these species in Brazil is probably largely underestimated or even neglected. Our records will also allow the development of future studies on new host-parasitoid interactions.

Acknowledgments To MQ Rezende, AL Perez, AR Bellinati, MB Paganella, BR Oliveira and A Vieira for their field assistance and to DC Ament for Phoridae species identification. This study was supported by research grants and fellowships to the authors from the "Conselho Nacional de Desenvolvimento Científico e Tecnológico" (CNPq) and from the "Fundação de Amparo a Pesquisa do Estado de Minas Gerais" (FAPEMIG). To the "Instituto Nacional de Ciência e Tecnologia de Hymenoptera Parasitoides da Região Sudeste do Brasil" (INCT-Hympar Sudeste), and to the "Universidade Paulista" for financial support to VAC and PHBT, respectively.

\section{References}

Berti-Filho E, Costa VA (1995) Perilitus coccinellae (Schrank, 1802) (Hymenoptera, Braconidae, Euphorinae), a parasitoid of Coleomegilla maculata (DeGeer) (Coleoptera, Coccinellidae). Rev Agric 70:80-80

Ceryngier P, Roy HE, Poland RM (2012) Natural enemies of ladybird beetles. In: Hodek I, van Emden HF, Honek A (eds) Ecology and behaviour of the ladybird beetles (Coccinellidae). Wiley-Blackwell, Chichester, pp 375-443, 561p

Gravena S (1978) Ocorrência de parasitismo em Cycloneda sanguinea (Linnaeus, 1763) no município de Jaboticabal, SP, Brasil. An Soc Entomol Bras 20:69-70

Guimarães JH (1977) Host-parasite and parasite-host catalogue of South American Tachinidae (Diptera). Arq Zool 28:1-131

Guimarães JH (1978) Hyalomyodes brasiliensis Townsend (Diptera, Tachinidae), a parasite of the introduced pest Lagria villosa Fabricius (Coleoptera, Lagriidae). Pap Avulsos Zool 32:35-40

Harterreiten-Souza ES, Togni PHB, Milane PVGN, Cavalcante KR, Medeiros MA, Pires CSS, Sujii ER (2012) Seasonal fluctuation in the population of Harmonia axyridis (Pallas, 1773) (Coleoptera: Coccinellidae) and co-occurrence with other coccinellids in the Federal District of Brazil. Pap Avulsos Zool 52:133-139

Klink CA, Machado RB (2005) The conservation of the Brazilian Cerrado. Conserv Biol 19:707-713

Lucas E (2012) Intraguild interactions. In: Hodek I, van Emden HF, Honek A (eds) Ecology and behaviour of the ladybird beetles (Coccinellidae). Wiley-Blackwell, Chichester, pp 343-374, 561p 
Michaud JP (2012) Coccinellids in biological control. In: Hodek I, van Emden HF, Honek A (eds) Ecology and behaviour of the ladybird beetles (Coccinellidae). Wiley-Blackwell, Chichester, pp 488-519, 561p

Mikami AY, Ventura UM (2008) Repellent, antifeedant and insecticidal effects of neem oil on Microtheca punctigera. Braz Arch Biol Technol 51:1121-1126

Noyes JS (2014) Universal Chalcidoidea database. http://www.nhm.ac. uk/chalcidoids. Accessed 22 Oct 2014

O'Hara J E (2014) Taxonomic and host catalogue of the Tachinidae of America North. http://www.nadsdiptera.org/Tach/Nearctic/ CatNAmer/Genera/Strongygaster.html. Accessed 22 Oct 2014
Rezende MQ, Campos JLA, Coelho LMB, Queiroz DL (2010) Coleoptera, Coccinellidae, Harmonia axyridis (Pallas, 1773): new record in Minas Gerais, southeastern Brazil. Check List 6:465-466

Riddick EW, Cottrell TE, Kidd KA (2009) Natural enemies of the Coccinellidae: parasites, pathogens, and parasitoids. Biol Control 51: 306-312

Silva RB, Cruz I, Figueiredo MLC, Pereira AG, Penteado-Dias AM (2012) Occurrence and biology of Dinocampus coccinellae (Schrank, 1802) (Hymenoptera: Braconidae: Euphorinae) parasitising different species of Coccinellidae (Coleoptera) in Neotropical region. Braz J Biol 72:215-219 